Check for updates

The BMJ

Cite this as: $B M J 2020 ; 369: m 2390$ http://dx.doi.org/10.1136/bmj.m2390 Published: 12 June 2020

\section{Covid-19: Government will belatedly publish recommendations for protecting ethnic minorities}

\author{
Gareth lacobucci
}

The UK government will belatedly publish recommendations for protecting minority ethnic groups from covid-19, amid claims that parliament was misled about the existence of additional material produced alongside a much criticised ${ }^{1}$ review by Public Health England (PHE).

The announcement came after Raj Bhopal, a professor of public health at Edinburgh University, told $B B C$ $N e w s^{2}$ that proposals to safeguard ethnic minorities were laid out in a separate 64 page document that PHE asked him to review four days before it published its main report on 2 June.

Bhopal said that the additional document contained recommendations and evidence from 4000 people and organisations and had "every hallmark of a [government] report ready to go to the press." But PHE did not publish recommendations with its report, prompting anger amid claims that the government had removed 3 and ignored ${ }^{4}$ evidence submitted by stakeholders.

On 4 June the equalities minister, Kemi Badenoch, told parliament that PHE did not make recommendations because it was unable to do so. Bhopal suggested that the government had misled parliament by failing to disclose that recommendations existed or that a second report on the impact of covid-19 on minority ethnic groups had been produced.

He said, "The public has expressed a great deal of disappointment, as well as the people who were part of this consultation, asking, 'Where have our voices gone?"”

\section{Final version}

PHE has said that the recommendations will be published and submitted to ministers next week. A spokesperson said, "The government commissioned PHE to conduct an epidemiological review to analyse how different factors can impact on people's health outcomes from covid-19. This was published in full on 2 June.

“In parallel, Professor [Kevin] Fenton, on PHE’s behalf, engaged with a significant number of individuals and organisations within the BAME [black and minority ethnic] community to hear their views, concerns, and ideas about the impact of covid-19 on their communities. We recognise this important contribution, and the interest it has generated, and will formally submit the final version to the minister next week and publish it at the same time."

But the Royal College of Physicians of Edinburgh said it was "deeply concerned" that the government had failed to acknowledge the existence of recommendations or a second report. The college's president, Angela Thomas, said that ministers must be "open and honest" about claims that recommendations were withheld from the public domain.

"Given recent events relating to racism and racial equality, it is incredibly important that the government is transparent with the public," she said. "The government must ensure that the second PHE report is made available to the public soon, so that they can scrutinise its recommendations.”

lacobucci G. Covid-19: Review of ethnic disparities is labelled "whitewash" for lack of recommendations. BMJ2020;369:m2208. doi: 10.1136/bmj.m2208 pmid: 32493696

2 Croxford R. Coronavirus: BAME safety plan not published. BBC News 2020 Jun 11. https://www.bbc.co.uk/news/health-53002968.

3 Moore A. Exclusive: Government censored BAME covid-risk review. Health Serv/2020 Jun 2. https://www.hsj.co.uk/coronavirus/exclusive-governmentcensored-bame-covid-risk-review/7027761.article.

4 lacobucci G. Covid-19: PHE review has failed ethnic minorities, leaders tell BMJ. BMJ 2020;369:m2264. doi: 10.1136/bmj.m2264 pmid: 32513658

This article is made freely available for use in accordance with BMJ's website terms and conditions for the duration of the covid-19 pandemic or until otherwise determined by BMJ. You may use, download and print the article for any lawful, non-commercial purpose (including text and data mining) provided that all copyright notices and trade marks are retained. 